\title{
COVID 19: The safety profile of common disinfectants used for sanitization
}

\author{
Wen Han Chooi $^{1 *}$, Shermaine Yee ${ }^{*}$ \\ ${ }^{1}$ Faculty of Medicine, Quest International University Perak, 122A, Jalan Haji Eusoff, 30250 Ipoh, Negeri Perak, Malaysia
}

$\dagger$ These authors have contributed equally to this work.

\begin{abstract}
With the recent outbreak of COVID-19, sanitization is a must for the community as daily safety prevention. The common ingredients found in disinfectant including glycol, sodium hypochlorite, silver ion, iodophor iodine and polyvinylpyrrolidone iodine. An ideal disinfectant should have a wide anti-microbial spectrum, low dermatologically toxicity profile, and stable storage properties. Glycol is widely used as a personal care product due to its low toxicity profile. Although it has a wide anti-microbial spectrum, it must be co-formulated with other agent due to its lower microbial killing strength. It has been demonstrated that sodium hypochlorite is not only capable of destroying bacteria and viruses but also about inactivating viral antigens by breaking down the high concentration protein resulting in the isolation of necrotic tissue particles. Yet, due to its strong alkaline $\mathrm{pH}$ and oxidizing capacity, it can cause corrosive reaction when mucous membranes and skin are in touch with it. Besides, silver ion also plays an effective role in curbing SARS coronavirus. It is used widely in disinfecting medical equipment, wound therapy, and utilized in water purification systems by its bacteriostatic and active ingredient properties. Researches have proven that iodophor iodine is effective in against non-enveloped virus in which $1 \%$ of povidoneiodine is effective against coronaviruses. However, it can cause a chemical burn, blistering, and skin sloughing if it used as skin disinfection. This report will discuss the safety of these disinfectants in sanitization.
\end{abstract}

Keywords: Coronavirus; sanitization; disinfectants; safety; skin

Received: $16^{\text {th }}$ August 2020

Accepted: $3^{\text {rd }}$ September 2020

Published Online: $18^{\text {th }}$ September 2020

*Correspondence: Wen Han Chooi \& Shermaine Yee, Faculty of Medicine, Quest International University Perak, Perak, Malaysia; chooiwenhan@gmail.com; groupashermaine@gmail.com.

Citation: Chooi WH and Yee S. COVID 19: The safety profile of common disinfectants used for sanitization. Prog Drug Discov Biomed Sci 2020; 3(1): a0000112. https://doi.org/10.36877/pddbs.a0000112

\section{Introduction}

Disinfectant is an agent with antiseptic properties that is effective against microbials. With the recent outbreak of COVID-19, studies have shown the importance of preventive measures especially the role of disinfectants in reducing the risk of transmission of this pandemic disease. There are many evidences that indicate this virus is transmitted through respiratory droplets or contact ${ }^{[1]}$. Direct transmission of this virus occurs when contaminated hands touch the mucosa of mouth, nose or eyes, whereas indirect contact transmission is facilitated by transferring of the virus from one surface to another by contaminated hands ${ }^{[2]}$. Inevitably, the onus is on us to practice hand hygiene that not only prevents the spread of COVID-19 virus but also other viruses and bacteria as well.

Among all types of disinfectants used for sanitization purpose, the most common traditional active ingredients include chlorine, alcohol and phenol ${ }^{[3]}$. Table 1 shows active ingredients commonly used in disinfectants, namely glycol, sodium hypochlorite, silver ion and iodophor iodine or polyvinylpyrrolidone iodine which are found to be effective against coronavirus. These chemicals although are effective against viruses and bacteria, but they also have risks associated with them ranging from skin irritation to long term effects, including occupational asthma.

The primary purpose of disinfectants is to eliminate microbials and pathogens. In other words, they are noxious to cells and none of them are completely harmless. However, there are some active ingredients used in the production of disinfectants that are safer for human health and the environmental than others. Hence, this report aims to discuss on the role of these common disinfectants in sanitization of COVID-19 and the safety of its usage. 


\begin{tabular}{|c|c|c|c|c|c|}
\hline Disinfectant & Advantages & Disadvantages & Shelf life ${ }^{[4]}$ & Anti-viral & Recommended dosage (concentration) \\
\hline Sodium hypochlorite & $\begin{array}{l}\text { Low toxicity profile } \\
\text { (medical disinfec- } \\
\text { tion), wide range } \\
\text { anti-microbial prop- } \\
\text { erties, cheap }\end{array}$ & $\begin{array}{l}\text { Skin irritation, swelling, } \\
\text { rash, pain, corrosive } \mathrm{e}^{[7,8]}\end{array}$ & 2 years $^{[9,10]}$ & +++ & $0.5 \%{ }^{[9,11,12]}$ \\
\hline Silver ion & $\begin{array}{l}\text { Low toxicity profile, } \\
\text { Potent antimicrobial } \\
\text { agent }^{[13-17]}\end{array}$ & $\begin{array}{l}\text { Argyria, silver der- } \\
\text { matitis, interrupt drug } \\
\text { absorption }^{[18-21]}\end{array}$ & $\begin{array}{l}\text { At least } 7 \\
\text { months }\end{array}$ & ++ & $0.01 \% \%^{[23]}$ \\
\hline Iodophor & $\begin{array}{l}\text { Wide range of anti- } \\
\text { microbial, Stable } \\
\text { storage, Low toxicity } \\
\text { profile }^{[24]}\end{array}$ & $\begin{array}{l}\text { Chemical burn, Blister- } \\
\text { ing, Skin sloughing }{ }^{[25]}\end{array}$ & 2 years $^{[4,26]}$ & ++++ & $1 \%$ at 6 to $75 \mathrm{ppm}^{[27-30]}$ \\
\hline Glycol & $\begin{array}{l}\text { Wide range of } \\
\text { anti-microbial, Low } \\
\text { toxicity profile }{ }^{[31,32]}\end{array}$ & $\begin{array}{l}\text { lower microbial killing } \\
\text { strength, Sensory skin } \\
\text { irritation }{ }^{[33,34,35]}\end{array}$ & 2 years $^{[36]}$ & + & 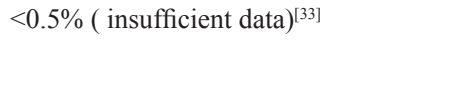 \\
\hline
\end{tabular}

Table 1. Summaries of characteristics of common disinfectants.

\section{Sodium hypochlorite}

Sodium hypochlorite was discovered in 1785 and has been commonly used on a large scale as a bleaching agent or disinfectant since then. It is generally used dissolved in water at various concentrations and appears as colourless or slightly greenish-yellow colour solution with corrosive properties. This chemical compound is also capable in dissolving proteins in high concentrations, inactivating viral antigens as well as having bactericidal and viricidal properties. A recent study reveals that surface disinfection with $0.1 \%$ sodium hypochlorite significantly reduces coronavirus infectivity on surfaces within $1 \mathrm{~min}$ exposure time ${ }^{[37]}$. Aside from the effective disinfection of coronavirus by $0.1 \%$ sodium hypochlorite, the use of bleach agents containing 5.25\%-8.25\% sodium hypochlorite is also recommended by $\mathrm{CDC}^{[12]}$.

As early as 1918, clinicians are keen to know the adverse effect of skin exposure to hypochlorite and its resulting chlorine. The action of the hypochlorite solution and chlorine on tissue results in the separation of particles of epithelial scales, hair, coagulated serum, necrotic tissue, and a period of at least 17 hours was needed for a gradual digestion of these substances ${ }^{[6]}$. It is found that hypochlorite's strong alkaline $\mathrm{pH}$ and oxidizing capacity is corrosive to mucous membranes and skin. A review on sodium hypochlorite isolated incidences of hypochloriteinduced delayed type hypersensitivity (allergic contact dermatitis), as well as immediate-type reactions from inhalation or topical challenge of sensitized individuals. A possibility of irritation and damage to the skin as a result of excessive and prolonged exposure to hypochlorite was also concluded in a review elsewhere ${ }^{[7]}$. Several cases reported also highlighted cases of dermatitis induced by exposure to sodium hypochlorite ${ }^{[38-40]}$. Almost $20 \%$ electrical workers that have prolonged exposure to chlorine mixture solution were diagnosed with skin diseases such as dermatitis, chloracne and folliculitis ${ }^{[8]}$. Vesicular eruption occurred to a female adult shortly after an irritant dermatitis caused by sodium hypochlorite found in the household bleach detergent. Direct immunofluorescence revealed linear deposits of $\operatorname{IgA}$ and $\mathrm{C} 3$ in the epidermal basement membrane and the serum of the patient con- tained $\operatorname{Ig}$ A that immunoblotted a $180-\mathrm{kD}$ polypeptide in extracts of human keratinocytes ${ }^{[41]}$. To fully understand this, the interaction between sodium hypochlorite and human stratum corneum were determined using human clinical trial study. Goffin et al. recruited fifteen volunteers to receive patch tests of a sodium hypochlorite for $15,30,45,60$, and $90 \mathrm{~min}$. Results showed that the stratum subclinical corneum alteration occurred, in the form of reduced skin conductance without significant TEWL change. Squamometry finding also confirmed sodium hypochlorite caused desquamating effect through loosening of its physical integrity ${ }^{[42]}$.

The use of $0.5 \%$ sodium hypochlorite or $1 / 100$ of the household bleach concentration for effective disinfectant properties is recommended by $\mathrm{CDC}^{[11]}$. Sodium hypochlorite is highly reactive and volatile. Due to its unstable chemical properties, sodium hypochlorite should be kept away from heat, sunlight, certain metals as well as poisonous and corrosive gasses, such as chlorine gas. The stability of sodium hypochlorite solution when used as disinfectants can be maintained for 2 years at $4^{\circ} \mathrm{C}$. Apart from that, sodium hypochlorite prepared at a $\mathrm{pH}$ of 6-8 can degrade substantially within 2-3 weeks. An increase in the $\mathrm{pH}$ of sodium hypochlorite would increase its stability and thus prolonging its shelf life ${ }^{[43]}$.

\section{Silver ion}

Metal ion, particularly silver ion is a potent disinfectant with a wide spectrum of antimicrobial properties against protozoa, bacteria and viruses ${ }^{[13,14,15,44,45]}$. Due to its broad coverage of antimicrobial activities, silver ions are used to disinfect medical equipment and in wound therapy ${ }^{[16,46,47]}$. It is also commonly utilized in water purification systems in hospital, community water systems, pools and $\mathrm{spa}^{[48]}$. A study using conventional plate count method and flow cytometric (FC) analysis found that silver ion, instead of bactericidal, it is bacteriostatic against $\mathrm{S}$. aureus and $\mathrm{E}$. coli bacteria ${ }^{[16]}$. Apart from that, silver ion as an active ingredient and carrier, such as in silver zirconium phosphate $(\mathrm{AgZrP})$, is effective in SARS coronavirus inactivation at a concentration of $23.4 \mu \mathrm{g} / \mathrm{mL}$ or above ${ }^{[49]}$. Another study also revealed that through a direct contact with 100 
$\mathrm{mg} / \mathrm{L}$ of $\mathrm{AgZrP}$ for 8 hours, complete elimination of E. coli and $99.9 \%$ of S. aureus is possible ${ }^{[50]}$. Another compound, silver zeolite at concentrations above $375 \mathrm{mg} / \mathrm{L}$ was reported to be effective in complete inactivation of both SARS-CoV-P8 and SARS-CoV-P11 strains of coronavirus within 2 hours ${ }^{[17]}$. Besides that, a study demonstrates that silver nanocluster/ silica composite coating deposited on facial masks is viricidal against coronavirus $^{[51]}$. Scientific evidences further showed that silver ion reacts with thiol group of 1-cysteine resulting in inhibition of essential enzymatic functions of microbes ${ }^{[16,52-55]}$. Increased production of reactive oxygen species (ROS) due to the action of silver-ion-mediated perturbation of the bacterial respiratory chain have been concluded in detail elsewhere ${ }^{[16,56]}$. The interaction of silver ions with nucleic acids ${ }^{[54,57,58]}$ and bacterial cell envelope ${ }^{[59]}$ could also play a role in its antimicrobial activity.

Several studies have reported a number of toxic effects of silver ion, including a decrease in the activities of glutathione peroxidase and lactate dehydrogenase as well as the peroxidation of membrane lipids ${ }^{[18-21]}$. An in-vitro study using human skin fibroblasts further demonstrates that silver ion toxicity is due to its induction of cellular oxidative stress and alteration of the intracellular zinc homeostasis of the cells ${ }^{[60]}$. Studies have shown that percutaneous absorption of silver ion in intact skin is lower compared to denuded skin ${ }^{[61,62]}$. The binding of silver ion with proteins and amino acid residues have been documented as the basis of silver-protein complexes found in the skin ${ }^{[47,61]}$ which most likely possible in slowing down the systemic absorption of silver, but may cause local effects as a reservoir may be formed for the prolonged release of silver ions in the $\operatorname{skin}^{[63]}$. Sizes of aggregates between $150 \mathrm{~nm}-2 \mu \mathrm{m}$ is found in both epidermis and dermis $^{[63,64]}$. Transmission electron microscope (TEM), atomic force microscopy and scanning electron microscopy with energy dispersive X-ray analysis (SEM-EDX) can be used in determining human skin penetration by silver ions ${ }^{[62-64]}$. A recent study highlighted that silver ions were released more by silver nanoparticles coated with oleic acid in the presence of phospholipids ${ }^{[65]}$. Although argyria is the most widely publicized clinical condition due to excessive silver ingestion, an incidence of argyria secondary to topical use of silver-based product have been reported ${ }^{[66]}$. Apart from argyria, cases of silver dermatitis have also been reported ${ }^{[67-76]}$ and a recent review deduced that other ingredients in silver-based products may be the cause for the allergic reaction ${ }^{[77]}$.

Despite the lack of scientific information to determine an appropriate range of doses for silver ion, $0.01 \%$ silver ion can be found in hand sanitizers ${ }^{[23]}$. Apart from this, it was also reported that the shelf life of nano silver colloids produced is at least 7 months ${ }^{[22,78]}$.

\section{Iodophor Iodine, polyvinylpyrrolidone iodine}

Iodophor is a variform complex compound that is formed by the polymer of iodine, surfactant, and reinforcer ${ }^{[79]}$. Povidone-iodine (Betadine) is the most popular iodophor, which effective against a wide range of microbial, as well as having stable storage and low toxicity profile ${ }^{[24]}$. A variety of crucial pathogens correlated with health care, namely vancomycin-resistant enterococci, methicillin-resistant Staphylococcus aureus, norovirus, Acinetobacter, and Clostridium difficile have been found susceptible to this disinfectant ${ }^{[80]}$. Furthermore, a research on disinfection of virus-contaminated non-porous inanimate surfaces using iodophor was conducted with adenovirus, coronavirus, coxsackievirus, and parainfluenza virus type 3 . The results of this study shows that this disinfectant might have enhanced activity against non-enveloped viruses and can improve both iodine and acid action if there is an appropriate non-ionic surfactant ${ }^{[27]}$.

Previous studies on disinfection options demonstrate that $1 \%$ povidone iodine ${ }^{[27]}$ and $50 \mathrm{ppm}$ iodine in iodophor ${ }^{[28]}$ is effective against coronavirus. In a study of 107 patients show that preoperatively, iodophor impregnated plastic adhesive drape ('Ioban') at the preliminary 24-hour incision site demonstrated a capability of lowering the infection risk from $15 \%$ to $1 \cdot 6 \%{ }^{[29]}$. The use of iodophor was statistically significant for wound infections with incidence of $6.8 \%$ to $2.7 \%$ in a series of 666 operations in a similar series of patients ${ }^{[30]}$. Besides, another research shows that a 10 minutes contact time of $4048 \mathrm{mg} / \mathrm{L} \mathrm{po-}$ vidone iodine can inactivate poliovirus with an average inactivation logarithmic value (4.00), thus effective in the inactivation of poliovirus ${ }^{[80]}$. Also, an animal study was used to conduct experimental investigations on the subacute toxicity of povidone iodine spray.

On the other hand, iodophor was tested to have a possibility in causing chemical burn, blistering and skin sloughing when used for skin disinfection purpose. Necrosis of the skin commonly results when there is an overdose of solution that comes in contact with the skin for an extended period of time ${ }^{[25]}$. As far as the concentrated product itself, National Chemicals suggests a two-year shelf life for stor$\operatorname{age}^{[26]}$.

\section{Glycol}

1,2-hexanediol belongs to the glycol class of disinfectant. It is also widely known for its use as an emollient, humectant and enhancers in cosmetics and personal care products $^{[34,81,82]}$. It is liquid form with light yellow colour with boiling point of $223^{\circ} \mathrm{C}$ and $0.951 \mathrm{~g} / \mathrm{mL}$ of density at $25{ }^{\circ} \mathrm{C}$. Although 1,2-hexanediol has wide anti-microbial spectrum, previous studies have shown that it must be co-formulated with other agent due to its lower microbial killing strength ${ }^{[34,83-89]}$.

1,2-hexanediol was tested and known to have a low toxicity profile ${ }^{[31,32]}$. In addition, scientific evidences have revealed that 1,2-alkanediols demonstrate enhanced risk for anti-microbial and sensory distress as their length of alkane chain grows ${ }^{[33,34]}$. Sensory skin irritation potential test were used to determine the skin reaction caused by 1,2-hexanediol.

Conversely, another study demonstrates 1,2-Hexanediol having high cytotoxicity properties against Raw 264.7 cells and HK- 2 cells. The results show that $0.5 \%$ concentration of 1,2-Hexanediol has considerable toxicity prop$\operatorname{erties}^{[35]}$. Another study was conducted using filter paper discs covered with twenty microlitres of 1,2-hexanediol in IQ test chambers, which are applied to each side of the na- 
solabial fold and cheek of the selected stingers. The results of stinging and burning reactions were recorded at 0.5 hour and 24 hours. A visual scoring was performed using a numerical erythema scale from 0 (none) to 3 (severe) and recorded which confirmed that 1,2-hexanediol has low skin irritation potential: $0.34 \pm 0.10$ for $1 \% 1$, 2 -hexanediol and $0.63 \pm 0.46$ for $20 \% 1,2$-hexanediol ${ }^{[33]}$. However, researches on the toxicity profile of 1,2-hexanediol reported by scientific journals are not enough to conclude. As far as the concentrated product itself, National Chemicals suggests a two-year shelf life for storage ${ }^{[36]}$.

\section{Discussion}

The role of disinfectants in our everyday life is crucial especially during this pandemic outbreak of COVID-19. Based on the data collected from recent studies about this disease, it is summarized that transmission from one person to another happens most commonly in close contact cases, via respiratory droplets. Apart from that, there are recent findings about incidences of people who are infected yet do not exhibit any COVID-19 symptoms which plays a role in this pandemic outbreak as well ${ }^{[2]}$. Current evidence from NIH suggests that SARS-CoV-2 is likely to remain active for hours to days on surfaces that are present in household or hospital settings ${ }^{[90]}$. Therefore, cleaning and disinfection of visible or non-visible dirty surfaces as well as hand hygiene are the effective preventive measures against COVID-19. Sodium hypochlorite is a widely used disinfectant due to its effectiveness, low cost and ease in preparation. It is also a potent sanitizer as it has strong oxidizing properties ${ }^{[91]}$. While sodium hypochlorite is very reactive, its useful properties are negatively impacted by factors including high temperature, presence of light and improper $\mathrm{pH}$ leve ${ }^{[10]}$. Other disadvantages of sodium hypochlorite also include health concerns related to skin irritation and mucous membrane damage, environmental contamination ${ }^{[38-40,92]}$ and its corrosive properties. Silver ion and its compound have long been discovered and since then used for disinfectant or antiseptic purpose ${ }^{[93]}$. It is effective because at low concentrations, it is able to show bactericidal and viricidal properties $^{[94]}$. Meanwhile, though iodophor may be less effective than sodium hypochlorite but it is also an effective sanitizer and disinfectant ${ }^{[95]}$. This chemical agent performs its role better in situations which have slightly acidic $\mathrm{pH}$ level ${ }^{[96]}$. Although iodine compound can stain surfaces easily, the EPA has confirmed its safety against the environment ${ }^{[31,32,34,83-89,97,98]}$. Glycol, namely 1,2-hexanediol although was not previously registered and used as a sanitizer or disinfectant, but when combined with other adjunct chemical agents, it is confirmed by EPA of its anti-microbial properties. Even though it has been proven to have the lowest toxicity level designated by the EPA, further investigations are still needed for this chemical agent as there is insufficient scientific evidences to support its effectiveness as a potent disinfectant. With regard to potential application in overcoming COVID-19, all chemical agents except glycol are supported with more scientific evidences of their effectiveness against coronavirus. However, sodium hypochlorite is the only disinfectant among these 4 chemical agents that is being recommended by WHO and CDC against COVID-19 for the time being ${ }^{[8,12]}$. In terms of tolerability, all 4 disinfectants are associated with risk of side effects. Case reports indicate the possibility of developing skin irritation for all chemical agents with the exception of silver ion that causes argyria. In relation to the preparation and shelf life of these active ingredients, factors such temperature, light and $\mathrm{pH}$ value are commonly important and changes in these factors can either prolong or shorten their shelf life $\mathrm{e}^{[10,14,91,97,99-102]}$. In light of these considerations, it is probably too early to have a definitive opinion about the best disinfectant which is effective against COVID-19 but iodophor may relatively be the safest chemical agent to be used for sanitization and disinfectant purpose of COVID-19.

\section{Conclusion}

The recent outbreak of the pandemic disease, COVID-19 has certainly introduced a new norm in the society: frequent and increased use of disinfectants and hand sanitizer. Consequently, the role, effectiveness, and safety of common disinfectants are important and should be considered. Although researches show that surface disinfection with sodium hypochlorite significantly reduces coronavirus infectivity on the surface, it is potent to cause skin irritation, swelling, rash, pain and has corrosive properties. In spite of the insufficient data about the toxicity profile and viricidal effect of silver ion and glycol against coronavirus, there is a recent study that demonstrates silica composite coating deposited on facial masks is viricidal against coronavirus. In addition, even though glycol plays an effective role as an inactive ingredient in antiseptic, but it cannot be used independently. Meanwhile, iodophor has been considered as the best disinfectant among these 4 chemical agents by having a stable storage and generally low toxicity profile. It is an ideal antiseptic especially in the current pandemic period but repeated exposure tends to cause side effects such as chemical burn, blistering, and skin sloughing especially if it is used in overdose. To avoid these side effects especially on dermatological aspect, the recommended dosage for sodium hypochlorite, silver ion, iodophor and glycol are $0.5 \%, 0.01 \%, 1 \%$ at $6 \sim 75 \mathrm{ppm}$ and less than $0.5 \%$ respectively. As far as the concentrated product itself, National Chemicals suggests a two-year shelf life of storage for all these chemicals except for silver ion, having a shelf life of at least 7 months when produced as nano silver colloids.

\section{Reference}

WHO [Internet]. Modes of transmission of virus causing COVID-19: Implications for IPC precaution recommendations. World Health Organization, 2020 Mar 29.

2. TEAM, W [Internet]. Q\&A: How is COVID-19 transmitted? Department of Communications, WHO Global, 2020 Jul 29.

3. Centers for Diseases Control and Prevention [Internet]. Chemical disinfectants guideline for disinfection and sterilization in healthcare facilities. 2008.

4. Nogueira JMF and Serôdio P. Determination of the expiration date of chemical solutions. Accred Qual Assur, 2003; 231-234

5. Heggers JP, Sazy JA, Stenberg BD, et al. Bactericidal and woundhealing properties of sodium hypochlorite solutions: The 1991 Lindberg Award. J Burn Care \& Rehabil, 1991;12(5): 420-424.

6. Austin, JH and Taylor HD. Behavior of hypochlorite and of chlora- 
mine-t solutions in contact with necrotic and normal tissues in vivo. J Exp Med, 1918; 27(5): 627-633.

7. Hostynek JJ, et al. Hypochlorite sensitivity in man. Contact Dermatitis, 1989; 20(1): 32-37.

8. Maroni M., et al. Occupational exposure to polychlorinated biphenyls in electrical workers. II. Health effects. Br J Ind Med, 1981 38(1): 55-60.

9. Centers for Diseases Control and Prevention [Internet]. FAQ about Sodium Hypochlorite Solution (SH). Household Water Treatment, 2014 Feb 18.

10. Johnson BR and Rameikis NA. Effective shelf-life of prepared sodium hypochlorite solution. J Endod, 1993; 19(1): 40-43.

11. Centers for Diseases Control and Prevention [Internet]. Frequently Asked Questions (FAQs) about Sodium Hypochlorite Solution(SH) Chlorination, 2014

12. Centers for Diseases Control and Prevention [Internet]. Cleaning and disinfection for households. National Center for Immunization and Respiratory Diseases (NCIRD), 2020 Jul 10

13. Pradeep, T. Noble metal nanoparticles for water purification: A critical review. Thin Solid Films, 2009; 517(24): 6441-6478.

14. Thurman RB, Gerba CP, and Bitton G. The molecular mechanism of copper and silver ion disinfection of bacteria and viruses. Crit Rev Environ Control, 1989; 18(4): 295-315.

15. Singh R., et al., E. coli inactivation by metals and effects of changes in water chemistry. J Environ Eng, 2019; 145(2): 04018136.

16. Jung WK., et al., Antibacterial activity and mechanism of action of the silver ion in Staphylococcus aureus and Escherichia coli. Appl Environ Microbiol, 2008; 74(7): 2171-2178.

17. Feied C. Novel antimicrobial surface coatings and the potential for reduced fomite transmission of SARS and other pathogens [Internet]. 2004. Avaialable from: https://graphics8.nytimes.com/images blogs/freakonomics/pdf/FeiedAntimicrobialSurfaces.pdf

18. Rogers KS. Variable sulfhydryl activity toward silver nitrate by reduced glutathione and alcohol, glutamate and lactate dehydrogenases. Biochim Biophys Acta, 1972; 263(2): 309-314.

19. Black RS, Whanger PD, and Tripp MJ. Influence of silver, mercury, lead, cadmium, and selenium on glutathione peroxidase and transferase activities in rats. Biol Trace Elem Res, 1979; 1(4): 313-324.

20. Williams D. The biocompatibility of silver. In First International Conference on Gold and Silver in Medicine. 1987.

21. Menon MP and Wright CE. A radiotracer probe to study metal interaction with human lactate dehyrogenase isoenzymes. J Protein Chem, 1989; 8(6): 757-766.

22. WHO [Internet]. Silver as a drinking-water disinfectant. Geneva, 2018.

23. Anson Bio-Technology Co. Ancos silver ion hand sanitizer. 2020.

24. Lowbury EJ and Lilly HA. Use of 4 per cent chlorhexidine detergent solution (Hibiscrub) and other methods of skin disinfection. Br Med J, 1973; 1: 510-515.

25. Kuller JM. Skin breakdown: Risk factors, prevention, and treatment. Newborn Infant Nurs Revi, 2001; 1(1): 35-42.

26. Reagents, LCL. Iodophor (disinfectant). Disinfectants \& Cleaning Solution, 2020.

27. Sattar SA, et al. Chemical disinfection of non-porous inanimate surfaces experimentally contaminated with four human pathogenic viruses. Epidemiol Infect, 1989; 102(3): 493-505.

28. Omidbakhsh N. and Sattar SA. Broad-spectrum microbicidal activity, toxicologic assessment, and materials compatibility of a new generation of accelerated hydrogen peroxide-based environmental surface disinfectant. Am J Infect Control, 2006; 34(5): 251-257.

29. Fairclough JA, Johnson D, and Mackie I. The prevention of wound contamination by skin organisms by the pre-operative application of an iodophor impregnated plastic adhesive drape. J Int Med Res, 1986; 14(2): 105-109.

30. Postlethwait RW, and Dillon ML. Iodophor for presurgical skin antisepsis. Arch Surg., 1964. 89: 462-465.

31. Levy SB, Dulichan AM, and Helman M. Safety of a preservative system containing 1,2-hexanediol and caprylyl glycol. Cutan Ocul Toxicol, 2009; 28(1): 23-24

32. Johnson Jr. W, et al., Safety assessment of 1, 2-glycols as used in cosmetics. Int J Toxicol, 2012; 31(5 suppl): 147S-168S.

33. Lee $\mathrm{E}$, et al. The influence of alkane chain length on the skin irritation potential of 1,2-alkanediols. Int J Cosmet Sci, 2011; 33(5): 421-425.

34. Okukawa, M., et al. Antibacterial activity of 1,2-alkanediol against Staphylococcus aureus and Staphylococcus epidermidis. J Oleo Sci, 2019; 68(8): 759-763.

35. Song U, and Kim J. Assessment of the potential risk of 1,2-hexanediol using phytotoxicity and cytotoxicity testing. Ecotoxicol Environ Saf, 2020; 201: 110796.

36. Company, D.C. Propylene glycols - Storage recommendations Dow Propylene Glycol USP/EP (PG USP/EP) 2014.

37. Kampf G, et al. Persistence of coronaviruses on inanimate surfaces and their inactivation with biocidal agents. J Hosp Infect, 2020 104(3): 246-251.

38. Eun HC, Lee AY, and Lee YS. Sodium hypochlorite dermatitis. Contact Dermatitis, 1984; 11(1): 45.

39. Habets JM, et al. Sensitization to sodium hypochlorite causing hand dermatitis. Contact Dermatitis, 1986; 15(3): 140-142.

40. Osmundsen PE. Contact dermatitis due to sodium hypochlorite Contact Dermatitis, 1978; 4(3): 177-178.

41. Goffin V, et al. Sodium hypochlorite, bleaching agents, and the stratum corneum. Ecotoxicol Environ Saf, 1997; 37(3): 199-202.

42. Pellicano R, et al. Linear IgA bullous dermatosis after contact with sodium hypochlorite. Dermatol, 1997; 194(3): 284-286.
43. Frais S., Ng YL, and Gulabivala K. Some factors affecting the concentration of available chlori. Int Endod J, 2001; 34: 206-215.

44. Abebe LS, et al. Point-of-use removal of cryptosporidium parvum from water: Independent effects of disinfection by silver nanoparticles and silver ions and by physical filtration in ceramic porous media. Environ Sci Technol, 2015; 49(21): 12958-12967.

45. Singh R, et al. Optimization of silver ion release from silver-ceramic porous media for household level water purification. Water, 2019; 11(4): 816 .

46. White RJ. An historical overview of the use of silver in wound management. Br J Nurs, 2001; 10(Sup4): S3-S8.

47. Lansdown $\mathrm{AB}$. Silver in health care: Antimicrobial effects and safety in use, in Biofunctional textiles and the skin. Curr Probl Dermatol, 2006; 33: 17-34.

48. Fewtrell L. Silver: Water disinfection and toxicity [Internet].. World Health Organization, 2014 Spring. Available from: https://www.who. int/water sanitation health/dwq/chemicals/Silver water_disinfection_toxicity_2014V2.pdf

49. Sugiura $\mathrm{K}^{-}$and Ono Y. Anti-coronavirus agent. Japan; WO2005037296A1, 2007

50. Tan S, et al. Antibacterial activity of silver-carried sodium zirconium phosphate prepared by ion-exchange reaction. J Ceram Soc Jpn, 2008; 116: 767-770.

51. Balagna $\mathrm{C}$, et al. Virucidal effect against coronavirus SARS-CoV-2 of a silver nanocluster/silica composite sputtered coating. Open Cerami, $2020 ; 1$.

52. Flemming CA, et al. Remobilization of toxic heavy metals adsorbed to bacterial wall-clay composites. Appl Environ Microbiol, 1990; 56(10): 3191-3203.

53. Liau SY, et al. Interaction of silver nitrate with readily identifiable groups: relationship to the antibacterial action of silver ions. Lett App Microbiol, 1997; 25(4): 279-283

54. Matsumura Y, et al. Mode of bactericidal action of silver zeolite and its comparison with that of silver nitrate. Appl Environ Microbiol, 2003; 69(7): 4278-4281.

55. Park HJ, et al. Silver-ion-mediated reactive oxygen species generation affecting bactericidal activity. Water Res, 2009; 43(4): 1027-1032.

56. Bragg PD and Rainnie DJ. The effect of silver ions on the respiratory chain of Escherichia coli. Can J Microbiol, 1974; 20(6): 883-889.

57. Yakabe Y, et al. Kinetic studies of the interaction between silver ion and deoxyribonucleic acid. Chem Lett, 1980; 9(4): 373-376.

58. Feng QL, et al. A mechanistic study of the antibacterial effect of silver ions on Escherichia coli and Staphylococcus aureus. J Biomed Mater Res, 2000; 52(4): 662-668.

59. Kẹdziora A, et al. Similarities and differences between silver ions and silver in nanoforms as antibacterial agents. Int J Mol Sci, 2018; 19(2): 444.

60. Cortese-Krott MM, et al. Silver ions induce oxidative stress and intracellular zinc release in human skin fibroblasts. Free Radic Biol Med, 2009; 47(11): 1570-1577.

61. Lansdown AB. A pharmacological and toxicological profile of silver as an antimicrobial agent in medical devices. Adv Pharmacol Sci, 2010; 2010: 910686

62. Larese FF, et al. Human skin penetration of silver nanoparticles through intact and damaged skin. Toxicol, 2009; 255(1-2): 33-37.

63. Bianco $\mathrm{C}$, et al. In vitro percutaneous penetration and characterization of silver from silver-containing textiles. Int J Nanomed, 2015; 10 1899-1908.

64. Bianco $\mathrm{C}$, et al. Characterization of silver particles in the stratum corneum of healthy subjects and atopic dermatitis patients dermally exposed to a silver-containing garment. Nanotoxicol, 2016; 10(10): 1480-1491.

65. Villanueva ME, Lanterna AE, and Vico RV. Hydrophobic silver nanoparticles interacting with phospholipids and stratum corneum mimic membranes in Langmuir monolayers. J Colloid Interface Sci, 2019; 543: 247-255.

66. Fisher NM, Marsh E, and Lazova R. Scar-localized argyria secondary to silver sulfadiazine cream. J Am Acad Dermatol, 2003; 49(4): 730-732.

67. Gaul LE and Underwood GB. The effect of aging a solution of silver nitrate on its cutaneous reaction. J Invest Dermatol, 1948; 11(1): 7.

68. Björnberg A. Toxic reactions to a patch test skin marker containing fuchsin-silver nitrate. Contact Dermatitis, 1977; 3(2): 101-102.

69. Catsakis LH and Sulica VI. Allergy to silver amalgams. Oral Surg Oral Med Oral Pathol, 1978; 46(3): 371-375.

70. White IR and Rycroft RJ. Contact dermatitis from silver fulminatefulminate itch. Contact Dermatitis, 1982; 8(3): 159-163.

71. Fraser-Moodie A. Sensitivity to silver in a patient treated with silver sulphadiazine (Flamazine). Burns, 1992; 18(1): 74-75.

72. Jankicevic J, et al. Contact sensitivity in patients with venous leg ulcers in Serbia: Comparison with contact dermatitis patients and relationship to ulcer duration. Contact Dermat, 2008; 58(1): 32-36.

73. Özkaya E. A rare case of allergic contact dermatitis from silver nitrate in a widely used special patch test marker. Contact Dermat, 2009; 61(2): $120-122$

74. Gaul L. Incidence of sensitivity to chromium, nickel, gold, silver and copper compared to reactions to their aqueous salts including cobalt sulfate. Annals Allergy, 1954; 12(4): 429-444.

75. Heyl T. Contact dermatitis from silver coat. Contact Dermat, 1979, 5(3): 197.

76. Agarwal S and Gawkrodger DJ. Occupational allergic contact dermatitis to silver and colophonium in a jeweler. Am J Contact Dermat, 2002. 13(2): 74

77. Group A and Lea A. Contact dermatitis with a highlight on silver: A review. Wounds, 2010; 22(12): 311-315. 
78. Deshmukh SP, et al. Silver nanoparticles as an effective disinfectant: A review. Mater Sci Eng C Mater Biol Appl, 2019; 97: 954-965.

79. Liu Z-B and HuQ. Overview on toxicological research on iodophors. Chin J Vet Drug, 2007.

80. Wang W-H, ChenW, Ge H, et al. Experimental study of efficacy of disinfectants in inactivation of virus. Chin J of Infect Control, 2005.

81. Foerster A and Neubert RHH. Dermal peptide delivery using enhancer molecules and colloidal carrier systems - part V(\#): Influence of enhancers on the permeation of PKEK through snake skin. Pharmazie, 2019; 74(3): 136-141.

82. Sagiv AE, Dikstein S., and Ingber A. The efficiency of humectants as skin moisturizers in the presence of oil. Skin Res Technol, 2001; 7(1): 32-35.

83. Choi E-Y. Effect of phenoxyethanol and alkane diol mixture on the antimicrobial activity and antiseptic ability in cosmetics. Kor J Aesthet Cosmetol, 2015; 13(2): 213-220.

84. Macinga DR, et al. Antimicrobial compositions. 2018, Google Patents.

85. Kobayashi A, Okamoto H, and Okada F. Antiseptic bactericides and cosmetics, drugs and foods containing the antiseptic bactericides. 2010.

86. Schmaus G, Lange S, and Joppe H. Synergistic mixtures of 1, 2-alkane diols. 2009, Google Patents.

87. Roeding J, et al. Synergistic mixtures of at least one 1, 2 alkanediol such as 1,2-hexanediol and 1,2-octanediol with a further compound having antimicrobial properties. 2007, Google Patents.

88. Wachman SL and Karlan S. Sterilant composition. 1992, Google Patents.

89. Krug B, et al. Wound and mucous membrane disinfectant. 2013, Google Patents.

90. National Institutes of Health [Internet]. Study suggests new coronavirus may remain on surfaces for days. NIH's National Institute of Allergy and Infectious Diseases (NIAID), 2020 Mar 24. Available from: https://www.nih.gov/news-events/nih-research-matters/study- suggests-new-coronavirus-may-remain-surfaces-days

91. Zhou X-W, W X-J, Liu J, et al. Studies on the oxidizing property of sodium hypochlorite solution. Chlor-Alkali Industry, 2006.

92. United State Environment Protection Agency [Internet]. Sodium and calcium hypochlorite salts. EPA Red Facts, 1991. Available from: https://archive.epa.gov/pesticides/reregistration/web/pdf/0029fact. pdf

93. Spear M. Silver: An age-old treatment modality in modern times. Plast Surg Nurs, 2010.

94. Lara HH, Garza-Treviño EN, Ixtepan-Turrent L et al. Silver nanoparticles are broad-spectrum bactericidal and virucidal compounds. J Nanobiotechnol, 2011.

95. Karsa RD. Decontamination of surfaces. Handbook for Cleaning, 2007.

96. Davis JG. Iodophors as detergent - Sterilizers. J Applied Bacteriol, 1962.

97. United State Environment Protection Agency [Internet]. Supporting Information for Low-Priority Substance 1,2- Hexanediol. Office of Pollution Prevention and Toxics, 2020 Feb 20. Available from: https://www.epa.gov/sites/production/files/2019-08/documents/support document for proposed designation_of 12-hexanediol.pdf

98. Johnson Jr. W, Bergfeld WF, Belsito DV, et al. Safety assessment of 1,2-glycols as used in cosmetics. Int J Toxicol, 2012.

99. Pathak SP and Gopal K. Evaluation of bactericidal efficacy of silver ions on Escherichia coli for drinking water disinfection. Environ Sci Pollut Res, 2012; 2012(19): 2285-2290.

100. Gélinas P, Goulet J, Tastayre GM, et al. Effect of temperature and contact time on the activity of eight disinfectants - A classification. J Food Prot, 1984

101. Barrett RB. A comparison of iodophor and sodium hypochlorite sanitizers. ASME 1970 Citrus Eng Conf, 2018.

102. Bao L and Peng DX. The stability observation of the povidone-idion solution at different $\mathrm{pH}$ and different temperature. Chin J Mod Appl Pharm, 1999. 